\title{
Influence of Corporate Control and Ownership Structure on the Value of Firms Listed at the Nairobi Securities Exchange
}

\author{
David Onguka \\ PhD Student, School of Business, \\ Department of Finance and Accounting, University of Nairobi, Kenya, \\ Professor Eramus S. Kaijage \\ Dr. Cyrus M. Iraya \\ Dr. Sifunjo E. Kisaka \\ Lecturers, School of Business, \\ Department of Finance and Accounting, University of Nairobi, Kenya
}

Doi:10.19044/esj.2018.v14n34p230 URL:http://dx.doi.org/10.19044/esj.2018.v14n34p230

\begin{abstract}
This study aimed at establishing the influence of corporate control and ownership structure on corporate values of companies listed at the Nairobi Securities Exchange. The paper tested the hypothesis that there is no significant moderating impact of ownership structure on the relationship between corporate control and corporate value growth based on Tobin Q and ROA measurements. The theory applied were agency theory, stewardship theory and stakeholder theory with the main anchoring theory being the agency theory. The study applied census survey for sixty four firms listed at the NSE. The time frame of analysis is five years between 2013 and 2017. Out of the 64 listed companies targeted, 58 were analyzed forming $90 \%$ of the population. The study applied census survey given that the population of the listed companies at the NSE were not many. Out of the 64 listed companies targeted, 59 were analyzed forming $92 \%$ of the population. Corporate control index was developed as a proxy for corporate control and ownership structure index was developed as a proxy for ownership structure. While ROA and Tobin $\mathrm{Q}$ were used to measure corporate value. The hypotheses were tested using both correlation and regression analysis. The key study variables of the listed companies were subjected to descriptive statistics and the results revealed a significant positive relationship between the variables. The study findings revealed significant moderating effect on the relationship between the value of the firm and its ownership structure.
\end{abstract}


Keywords: Corporate control, ownership structure, agency theory, firm value.

\section{Introduction}

The topic of corporate control has attracted a great interest of scholars, regulators and society in general. The motivation of this study is to determine the cause of corporate underperformance which continue to be experienced globally, regionally and even locally despite institution of regulatory bodies and how this is influenced by corporate control and ownership structure. A number of studies (Shleifer \& Vishny, 1997; Stulz, 1990 and Solomon et al. 2013) have attributed this problem to separation of ownership and control resulting in divergent of concern between agents and principles which results in agency cost.

According to Berle and Means (1932), as the gap between possession and control continue to increase with increasing large organizations and decrease in equity ownership, agency cost also increases. This development provide a favorable environment for managers to pursue their own interest rather than that of the shareholders which indicates the presence of unhealthy association problems arising as a result of agency conflict (Jensen \& Meckling, 1976). The agency costs result from management consuming perquisites, suboptimal investments and general inefficiency. Corporate control practices improves company's efficiency and effectiveness through proper supervision and governance thereby mitigating on agency costs in an effort to bring into line the interest of company managers with that of owners in optimizing corporate value (Shleifer \& Vishny, 1997). However, according to Barclay and Holderness (1991) when the desire to obtain private benefit of control overrules the incentive effect, managerial owners can reduce corporate value. Demsetz and Lehn (1985) argued that there is no relationship between having managers as owners or part owners and corporate value given that the ownership structure is a compromise based on management view of how to optimize the performance of the company using an optimal mix of debt and equity.

The structure of ownership is important in the link between corporate control and company's value as the owners' objective is to maximize their returns by strengthening control issues. According to Hubbard and Palia (1999) ownership structure of a company can be endogenously determined by its contracting environment such as whether there are high chances of perquisite consumption or not and whether the capital structure imposes adequate pressure on management to increase company's value. Jensen (1986) suggested corporate governance, corporate financial policies and ownership structure as some of the possible mechanism for mitigating agency conflicts resulting from widely dispersed share ownership and weak controls. Agency theory analyses the contribution of corporate control and ownership structure 
in reducing agency costs and conflict and how this eventually translates into improvement in corporate value and sustenance. Stewardship theory holds that conflict of interest between management and owners is none existent and that the aim of corporate control is to identify the mechanism for most efficient coordination between the two, to enable them optimize capital structure and ownership that maximizes shareholders value.

\section{Corporate Control}

The fundamental understanding in the field of corporate control has its basis on the fact that there is a potential problem originating from the agency conflict which is necessitated by the growth in size and complexities of corporation (Denis, 2001). According to Ashbaugh et al. (2004) the management and the board have been tasked with the pursuit of impactful corporate control which is of great importance to the society as a whole since it improves the utilization of resources. Therefore resources will always flow to where it is effectively and efficiently utilized and managers who fail to do this are eventually replaced or the business collapses. The underperformance leading to collapse of significant corporations like WorldCom and Enron among others underscores the importance of good corporate control (OECD, 2004). A standardized structured corporate control index (CCI) was made as a proxy for corporate control and relied on intentional surveys got from secondary statistics. The index values range was between 0 and 100 where the high the score, the better the company is governed.

Corporate Control mechanism can be classified as internal or external. Internal control mechanism refer to the extent to which the mechanism influence the systems and procedures adopted by the corporation and generally includes board sizes, board remuneration, board independence, top management compensation, financial policy, frequency of board meetings, CEO duality and ownership concentration (Dalton \& Daily, 1992). The external control mechanism refers to the extent to which forces outside of the corporation exert influence and control over the corporation value creation. Their focus is to protect the interest of the shareholders, these includes major Institutional shareholders, Government and other regulatory agencies and financiers (Dominic \& Member, 2015).

\section{Ownership Structure}

Ownership structure is the base of corporate management, company owners are those who own the privileges to control the company and the right to distribute the company's profits or remaining income (Hansmann, 2000). The structure of ownership can be viewed in two ways: ownership concentration and ownership mix (Gursoy \& Aydogen, 2002). The former is about the share of the significant owner and is affected by complete risk and 
monitoring expenses (Thomsen \& Pedersen, 2000). On the other hand the latter is about the characteristics of the significant stakeholder. Lee (2008) referred to this division as concentration and mix of ownership. According to the theory, concentrated ownership is expected to mitigate the agency problem as it provide a mechanism and framework of enhancing corporate control.

Ownership mix also plays a crucial role in value creation and therefore was considered along with state and foreign owners. Depending on the appropriateness of board structure, ownership structure and corporate financial policies have been suggested as potential mechanisms to control for agency problem arising from dispersed ownership (Jensen, 1986). Agency problems can be aggravated by high voting rights which may result in pyramid ownership structures and crossholding. The resulting situation often results in over-reliance on debt resulting from main shareholders desire to preserve their shareholding from dilution. Claessens et al. (2002) referred to this phenomenon as non-dilution entrenchment.

\section{Firm value}

Eyenubo, (2013) defined firm value as the extent to which the objectives of the company have been realized within a given time period. According to Black et al. (2006) strengthening corporate control ensures that the management will be more aggressive in sourcing for and investing in projects with high returns, optimize resources available to achieve this, as well as in being more creative in evaluating alternative investments. Corporate value or the firm performance over the period was calculated based on asset returns (ROA) and Tobin's Q which, unlike asset returns, combines both accounting and markets elements in its measurement criteria. It measures how efficient and effective management is in employing company resources to generate corporate value (Kiruri, 2013)

\section{The Nairobi Securities Exchange}

Nairobi Securities Exchange is the regulatory body in Kenya, charged mainly with ensuring compliance to corporate control and governance principles. Some of the regulations to be adhered to by the listed firms are intended to eliminate weaknesses identified by previous studies and to strengthen and promote effective corporate control for optimal corporate performance. Laws have been instituted to guide and enforce governance structures, reporting and compliance for the listed firms some of which include the companies Act and the CMA act (Mwangi et al., 2014). Despite these measures some of companies listed at the NSE continue to show fundamental weakness and poor performance. A few of them have collapsed while some are in the brink of failures (Omondi \& Muturi, 2013). Some of the recent failures were Imperial Bank, Dubai bank and Chase bank. Other weaknesses 
noted are the continuing poor performance shown by Kenya Airways, Uchimi Supermarket among others, that have eroded, to some extent, the public confidence in its ability to regulate the corporations resulting in increased capital flight, weak capital formation and poor economic performance. Argument on whether it is the control failure, financial distress or nature of the ownership or combination of these that is responsible for the failure continues. It is with this background that we intend to establish the influence of corporate control on company value as moderated by ownership structure.

\section{Research Problem}

There is an urgent need to determine the loss of confidence in the capital market by current and potential investors, the insolvency of a number of large corporations in Kenya, regionally and worldwide and reason for persistent agency problem. Some of these problems have been linked to the division of ownership and controls as corporations grow larger and more complex forcing owners to use the services of professional who have the capacity to manage such complex set up. Berle and Means (1932) findings narrowed down this problem to agency costs. Agency problem arises due to differences in interest of shareholders and managers. Some of the high profile failures are Air Zimbabwe in Zimbabwe, J.P Morgan, Fredie Mac and Lahmen Brothers and worldcom in USA and Europe. According to Hermalin \& Weisbach, 2003, such failures points to ineffectiveness or failure of corporate control system resulting in fraudulent activities and inefficiencies.

Despite the substantial evidence of positive influence of corporate control, there seems to be a deep rooted problems in some corporate governance systems and quality of corporate reporting (Chagbadari, 2011). Investors have questioned the effectiveness of current control mechanism put in place and are hesitant to commit without clear evidence that correct action has been taken and the stock market can be depended upon to generate wealth without interference, suboptimal activities of management and inbuilt inefficiencies. The insolvency of previously respected corporations due to misappropriation and pursuit of personal interest by some management has awaken discussion on the importance of control and ownership structure on firm performance. The predominant of sub-optimal practice done by the executive team intended to gain financial advantage at the expense of owners' results in corporate under-performance. Although corporate control principles and institutions tasks with corporate governance have achieved a significant improvement in corporate stability and performance, there is still need for concrete action on the areas of limitation in depth and understanding of all key variables affecting corporate performance and their inter-relations. 


\section{Research Objective}

To establish the direct influence of corporate control on corporate value growth and the impact of ownership on the relationship between corporate control and firm value of the NSE listed firms.

\section{Literature Review}

\section{Agency Theory}

The agency theory is the anchoring theory in the research as it highlights the agency costs arising from the continuing divide of firm ownership from control. It provide for corporate control rules and regulations that ensure that the board takes its actions in line with owners expectation of optimizing returns and value to maximize company's growth. It also allows for the capital structure to be used to alleviate agency costs by aligning further the shareholders and management interest through increased pressure to perform on the agents. Jensen and Meckling (1976) identified certain assumptions of agency theory, the key of which are uncertainty and imperfect monitoring. The principal experiences uncertainty in his inability to establish the return on investment or the maximization of shareholder's wealth. He is also not able to perfectly monitor the activities of the agent. There is also information asymmetry resulting from distorted flow of information between the principal and the agent. Divergent of interest also results in conflict in the relationship as both agent and principal are utility maximizes.

Critics of the theory points out that it focuses on the divergent relationship alone thereby overlooking the divergence of relationships between various actors and their inter-dependencies (Hermalin \& Weisbach, 2003). These actors are likely to be unique and have symbiotic relationship that may not be easily mapped to such divergent stand of the theory. Not all agents are opportunistic and self-centred as there are some who was act as true captain of the ship as long of the compensation and reward is worked out to their satisfaction.

\section{Stewardship Theory}

Donaldson and Davis (1994) pioneered Stewardship theory. This is a relationship based on trust which is developed as an alternative to agency theory. The theory argues that human beings are by nature social being and therefore have a converging interest as their needs are interrelated, meaning that both management and shareholders are interested, deep down, in optimizing company value. The theory considers convergence of goals amongst parties involved as opposed to just the agent's self-interest. It holds that the only aim of corporate control is to identify the mechanism and structures that aid the most efficient coordination amongst owners and management which would enable them to optimize on capital structure and 
ownership structure that maximizes shareholders value and that owners and company executive work in harmony always with one similar objectives. According to Olson (2008), it was developed so that executive managers of a company acts as captains of the organization and in the best interest of the shareholders.

\section{Stakeholder Theory}

This theory supports the concept of corporate control in a more robust way than agency theory and is therefore seen as an advancement of this theory. This theory was advanced by Jensen and Meckling (1976) to take into account not only the interest of the shareholders but also the interest of all those who affect or are affected by the corporation. The stakeholders include employees, customers, suppliers, banks, local community and shareholders. The managers have therefore the additional responsibility of ensuring that no stakeholder is dissatisfied in one way or the other. According to Sternberg (1997), it is a doctrine that the corporation should be run not only for the financial and corporate value growth benefit of the shareholders but for the benefit of all concerned parties.

\section{Corporate Control, Ownership Structure and Company Value}

Empirical evidence shows that several studies have found a positive link between corporate control, ownership structure and company value. However, this linkage cannot be complete without looking at the moderating impact of ownership structure. Wanjugu et al. (2015), studied the effect of ownership structure and corporate governance on profitability and market value of privatized companies in Kenya. Regression model with a robust standard error alternative was applied. The result indicated that government ownership and board composition have a positive impact on ROA and Tobin's $\mathrm{Q}$, while women directors have negative impact. The research focused only on privatized former government owned or controlled companies but failed to do a comprehensive research of all companies listed at the NSE.

Lauterbach and Vaninsky (1999) studied the structure of company ownerships and its returns of listed companies in Israel. They engaged the DEA method of analysis. They finding showed that when companies are run by owners or relatives, they are less efficient and achieve poorer performance than when managed by professionals. The study considered ownership structure as the independent variable in relations to Firm performance with no intervening or moderating variables. This study has considered ownership structure as a moderating variable.

M'Ithiria and Musyoki (2014) conducted a research on corporate governance, ownership structure perspective and company value. Critically reviewed both theoretical and empirical literature. Their conclusion was that 
that empirical results found so far are mixed, meaning that there is no definite evidence of the impact of corporate governance on company value based on ownership structure. They failed to consider the intervening effect of capital structure on company value. Okiro, Aduda and Omoro (2015) examined influence of corporate governance and capital structure on value of companies listed at the EAC Securities Exchange. They used descriptive cross-sectional design. Their findings indicated a positive link between corporate governance and company value. They also found that there is a significant intervening impact of capital structure on the link between corporate governance and company value which is also positive. The two studies did not consider the moderating impact of ownership structure on the link between corporate governance and ownership structure.

\section{The Conceptual framework}

The effect of the causation variable over response variable is not only direct but also through a moderating variable (ownership structure). This moderating variable role has been shown by $\mathrm{H}_{2}$. The moderating variable of ownership structure as measured by ownership concentration, foreign ownership and state ownership and is expected to affect company value by reducing agency cost and forcing management to invest only in positive return project, consume less perquisites and increase efficiency. The direct relationship between corporate control and firm performance is shown by $\mathrm{H}_{1}$.

Figure 1: The Conceptual Model

Independent Variable

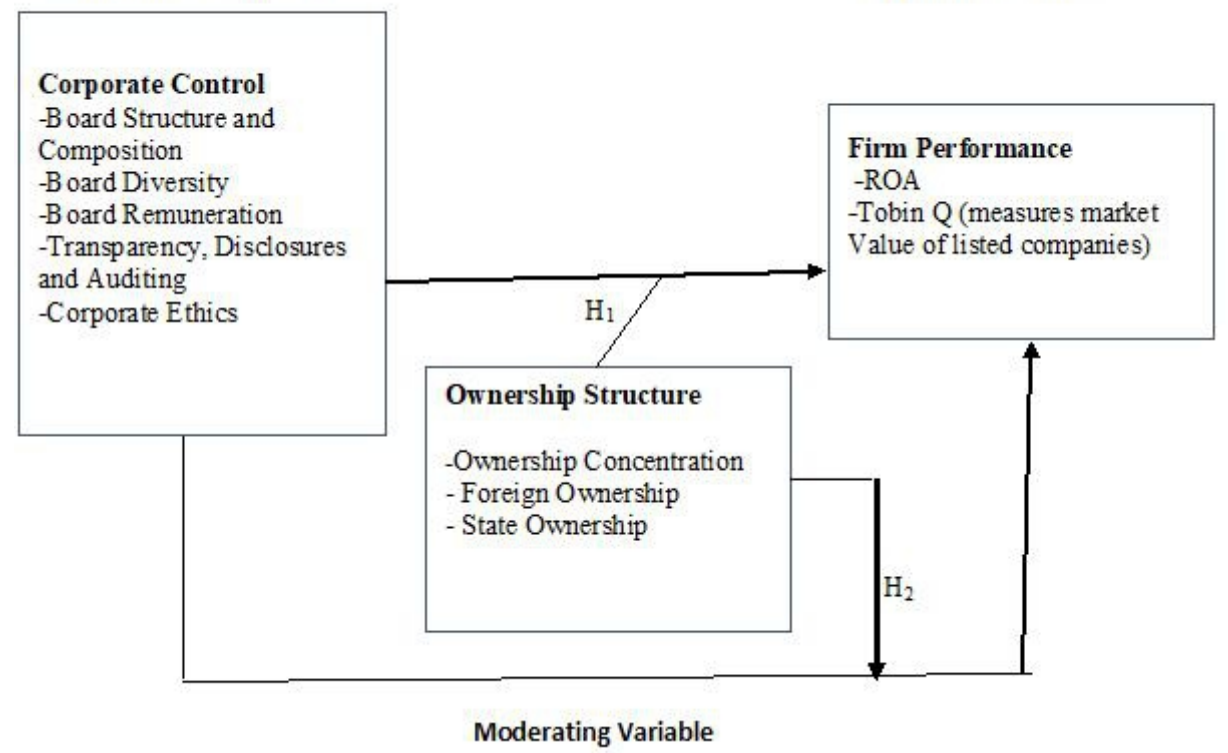

Source: Author (2018) 


\section{Data Collection}

This research employed secondary data acquired from past financial statements after examining them, an index was formed for corporate control. For firm performance, the fiscal statement was analyzed to find ROA and Tobin Q. Secondary Data was obtained from companies' websites, financial statements and other records filed with NSE. Where necessary data could not be obtained from third parties and websites, the same were requested directly from the company's management. The period of research covered 2013 to 2017.

The study applied a corporate control index based on data from several authorities including the NSE exchange and others like OECD, CACG. The CCI were structured and developed to represent corporate control bifurcated into 43 objective aligned questions derived from the collected data obtained from secondary sources. CCI were assigned between of 0 to 100 values. According to Brown and Caylor, (2004) better governed firms are expected to have higher values.

A structured ownership index (OSI) was developed from data obtained from secondary sources including NSE and others like OECD, CACG. The OSI was constructed as a proxy for ownership structure of the listed companies and these were captured into 24 objective linked questionnaires from the above data. A similar index was used by LaPorta et al., (2002).

\section{Data Analysis}

A multivariate regression model was applied to determine the link between corporate control and company's Value. The first hypothesis was tested based on the equation below:

$\mathrm{Y}_{\mathrm{it}}=\alpha+\beta_{1} \mathrm{CC}_{\mathrm{it}}+\varepsilon_{\mathrm{it}}$

Where $\mathbf{Y}$ represents corporate value or firm performance (ROA \&Tobin Q), $\boldsymbol{\alpha}$ is the intercept, $\boldsymbol{\beta}_{\mathbf{1}}$ is regression coefficient, $\mathbf{C C}$ is the corporate control composite (Measured by Corporate Control Index (CCI)), $\varepsilon$ is a random error term, $\mathbf{i}$ is the companies count and $\mathbf{t}$ is the duration of the research.

The approach proposed by Fairchild and Mackinnon (2009), for testing moderation was applied. It entailed moderation of the impact of Ownership Structure (OS) on the link between Corporate Control (CC) and company's value $(\mathrm{Y})$. The equation is stated below:

$\mathrm{Y}_{\mathrm{it}}=\alpha+\beta_{1} \mathrm{CC}_{\mathrm{it}}+\beta_{2} \mathrm{OS}_{\mathrm{it}}+\beta_{3} \mathrm{CCOS}_{\mathrm{it}}+\varepsilon_{\mathrm{i}-}$

The representation: $\alpha$ is the constant, OS - is the composite of Ownership Structure variables (Measured by Ownership Structure Index (OSI) $\beta_{1}$ is the coefficient of the causation variable, $\beta_{2}$ is the coefficient of the moderating variable, $\beta_{3}$ is the coefficient of the moderating variable impact. If $\beta_{3}$ and zero varies, moderation impact of the OS -Y relationship is significant. 


\section{Descriptive statistics}

The descriptive statistics refer to measurement of data in terms of minimum, maximum, mean, standard error of estimates. It also include measures of symmetry - skewness and flatness or sharpness of data - kurtosis. Mean is the average of all numbers and it is a measure of central tendency including mode, median and range. The extent to which the regression line prediction is corrected is tested by the standard error. Skewness measures the probability based on the tails relative sizes. Kurtosis determines, in reference to normal distribution, the degree of heaviness or lightness of tailed data. It is a measure of combined size of the two tails.

The study looked at measures of corporate control such as corporate ethics, transparency, disclosure and auditing, board remuneration, board diversity, board structure and composition among companies listed at the Nairobi Securities Exchange as shown below. 
Ownership Structure

\section{Test on ownership structure}

Table 1. Ownership Structure

\begin{tabular}{|c|c|c|c|c|c|c|c|c|c|}
\hline & $\mathrm{N}$ & Mean & Max. & Min. & Std. Dev. & Skewness & Kurtosis & Jarque-Bera & Probability \\
\hline $\begin{array}{l}\text { Presence of outside blockholders } \\
\text { (more than 10\%) }\end{array}$ & 58 & 0.794 & 0.955 & 0.352 & 0.4326 & 0.265 & 2.315 & 3.302 & 0.0794 \\
\hline The CEO own shares & 58 & 0.945 & 0.914 & 0.331 & 0.3651 & 0.756 & 3.015 & 12.987 & 0.0011 \\
\hline $\begin{array}{l}\text { Directors ownership other than } \\
\text { the CEO and Chairman }\end{array}$ & 58 & 0.699 & 0.865 & 0.579 & 0.415 & 0.875 & 3.455 & 16.578 & 0.0061 \\
\hline $\begin{array}{c}\text { Chairman or CEO is block } \\
\text { holder }(10 \%)\end{array}$ & 58 & 0.722 & 0.897 & 0.763 & 0.341 & 0.514 & 2.401 & 10.391 & 0.0027 \\
\hline $\begin{array}{l}\text { Concentration of ownership (top } \\
\text { five) }\end{array}$ & 58 & 0.756 & 0.921 & 0.406 & 0.335 & 0.032 & 3.491 & 3.661 & 0.0795 \\
\hline Dividend Policy & 58 & 0.675 & 0.731 & 0.309 & 0.3254 & 0.731 & 3.431 & 8.521 & 0.0041 \\
\hline Other staff benefits disclosure & 58 & 0.755 & 0.794 & 0.639 & 0.521 & 0.784 & 2.484 & 8.973 & 0.0026 \\
\hline Disclosure of CS report & 58 & 0.705 & 0.864 & 0.886 & 0.5404 & 0.678 & 3.451 & 8.521 & 0.0015 \\
\hline Average Score & 58 & 0.75638 & 0.86763 & 0.53313 & 0.40944 & $\mathbf{0 . 5 7 9 3 8}$ & 3.00538 & 9.11675 & 0.02213 \\
\hline
\end{tabular}


The findings as tabulated above shows an overall average mean of 0.75638 for ownership structure which is a significant impact on corporate value. The presence of outside block-holders with over 10\% shareholding has an average mean of 0.945 of 0.4326 . Cases where CEO also owns shares of the listed firms averaged 0.945 with a standard deviation of 0.3651 . Directors' ownership other than CEO and Chairman Mean was 0.699 and a standard deviation of 0.415. Cases where either chairman or the CEO where the block holders with $10 \%$ or more of shareholding mean was 0.722 and standard deviation of 0.341 . Concentration of ownership in the top $5 \%$ of the shareholding mean was 0.756 and standard deviation of 0.335 while listed corporations with dividend policy results into a mean of 0.675 and a $\boldsymbol{\alpha}$ of 0.3254 . Listed firms which disclosed staff benefits other than wages and salaries mean was 0.755 with a standard deviation of 0.521 while those which disclosed their capital structure reports generated a mean of 0.705 and a $\boldsymbol{\alpha}$ of 0.5404 .

Analysis of skewness revealed that the average score for ownership structure skewness averaged 0.57938 which is not far from zero indicating that this is a normal distribution. Kurtosis measurement of constructs is more of less equal to 3 meaning that this is a normal distribution with a bell shape (mesokurtic).

Among the list companies at NSE, outside shareholders with $10 \%$ or more were quite significant at $79.4 \%$ while cases where CEO own shares were also high at $94.5 \%$ this coupled with top five percent shareholding proportion standing at $75.6 \%$ indicated a strong concentration of shares. According to Sheilfer and Vishny (1997) such investors with large stake has the motivation to supervisor management and collect information needed to maximize their share value hence the achievement of higher corporate value. Waweru and Riro (2013) findings indicated that the composition of the board and the structure of ownership had the most impact on corporate performance of the NSE listed companies. The conclusion of the study supported the existing literature's general empirical findings that ownership structure has a significant and positive impact on corporate value growth.

\section{Corporate Control and firm performance}

The aim of this study is partly to determine significance of corporate control on firm performance for companies listed at NSE. This objective was examined based on its sub-variables of board structure and composition, board diversity, director's salaries and allowances, transparency, auditing and code of conduct. The constructs were examined against the indicators of corporate value in an effort to establish their impact. The adequacy of the combined impact to support the hypothesis was tested using a number of regressions. The firm performance measurement variables of Tobin $Q$ and ROA were 
applied to establish the relationship. Information obtained from financial reports of the NSE listed companies formed the basis of the analysis. The null hypotheses of the study are stated below:-

\section{H1a: There is no significant relationship between corporate control and} ROA for NSE listed companies.

Hypothesis 1a sought to establish the link between corporate value and return on assets and was tested using the equation below

$\mathrm{Y}=\beta_{0}+\beta_{1} X$

Where;

$\mathrm{X}$ represent corporate control and $\mathrm{Y}$ represents ROA.

Table 2: Regression Model of Corporate Control against ROA

\begin{tabular}{|c|c|r|r|r|r|}
\hline Model & $\mathrm{R}$ & $\mathrm{R}^{2}$ & Adjusted $\mathrm{R}^{2}$ & $\begin{array}{c}\text { Std. Error of the } \\
\text { Estimate }\end{array}$ & Durbin-Watson \\
\hline 1 & $.755 \mathrm{a}$ & .676 & .678 & .117935 & 1.491 \\
\hline
\end{tabular}

Index;

a. Constant, Corporate Control

b. dependent variable: ROA

The table above present model's summary for the relationship between corporate controls and ROA. It is evident that effect of corporate control on ROA is significant with a regression $(\mathrm{R})$ of 0.755 . Therefore corporate control explained up to $67.8 \%,\left(\mathrm{R}^{2}=.678\right)$ of the total variation in return on asset is attributed to changes in corporate control. The remaining $35.2 \%$ is explained by the other variable.

\section{ANOVAa - Corporate Control and ROA}

H1b: There is no significant relationship between $\mathrm{CC}$ and Tobin $Q$ among the NSE listed companies.

Hypothesis sought to establish the relationship between the stated variables for listed companies at NSE. A regression of corporate control on corporate value was done using the equation below.

$\mathrm{Y}=\beta_{0}+\beta_{1} \mathrm{X}$

Where

$\mathrm{X}$ represents corporate control and $\mathrm{Y}$ denote Tobin $\mathrm{Q}$. 
Table 3: Effect of Corporate Control Index on Tobin's Q

Summary of the Model.

\begin{tabular}{|c|c|c|c|c|c|}
\hline Model & $\mathrm{R}$ & $\mathrm{R}$ Sq. & Adjusted R Sq. & $\begin{array}{c}\text { Std. Error of } \\
\text { the Estimate }\end{array}$ & $\begin{array}{c}\text { Durbin - } \\
\text { Watson }\end{array}$ \\
\hline 1 & .601 & .324 & .312 & .6734401 & 1.577 \\
\hline
\end{tabular}

Constant, CCI

Dependent Variable: TOBIN Q

\begin{tabular}{|c|c|c|c|c|c|}
\hline \multicolumn{7}{|c|}{ Coefficients } \\
\hline $\begin{array}{c}\text { (Constant) } \\
\text { CCI }\end{array}$ & \multicolumn{2}{|c|}{$\begin{array}{c}\text { Unstandardized } \\
\text { Coefficients }\end{array}$} & $\begin{array}{c}\text { Standardized } \\
\text { Coefficients }\end{array}$ & $\mathrm{t}$ & Sig. \\
\cline { 2 - 6 } & $\mathrm{B}$ & Std. Error & Beta & & \\
\hline $\begin{array}{c}\text { (Constant) } \\
\text { CCI }\end{array}$ & -1.387 & .283 & & -5.641 & .000 \\
\hline
\end{tabular}

Dependent Variable: TOBIN Q

ANOVA

\begin{tabular}{|c|c|c|c|c|c|}
\hline Model & $\begin{array}{c}\text { Sum of } \\
\text { Square }\end{array}$ & Df & $\begin{array}{c}\text { Average } \\
\text { Square }\end{array}$ & F & Sig. \\
\hline Regression' & 37.218 & 1 & 37.218 & 112.017 & .000 \\
Residual & 221.556 & 289 & 0.471 & & \\
Total & 258.774 & 290 & & \\
\hline
\end{tabular}

Dependent Variable: TOBIN Q

Predictors: (Constant), CCI

The results show that a weak relationship exists between the two variables with regression $\mathrm{R}$ of 0.601 . The means that only $32.4 \%\left(\mathrm{R}^{2}=.324\right)$ can be explained by corporate control index (CCI) of the Tobin's Q while the balance $67.6 \%$ is accounted for by other variables. At p-value greater than 5 , $\mathrm{F}$ value is 112.017 indicating that corporate control index based on Tobin's Q measurement shows a significant influence on company's returns. Null hypothesis is thus rejected.

In agreement to this, Gompers at al. (2003) who opined that corporate governance as calculated by Tobin's $Q$ had a significant and positive effect on firm's returns.

\section{Moderating Effect of Ownership Structure on Corporate value}

Our second aim is to determine the effect of ownership structure on the linkage between corporate control and the value of firms listed at the NSE. In an effort to establish the relationship, the below hypothesis was formulated in null form.

H2a: There is no significant effect of ownership structure on the relationship between corporate control and ROA.

To achieve this objective, effects of the independent variable (corporate control) and moderating variable (ownership structure) on the dependent variable (corporate value as measured by ROA) and the interaction 
between corporate control and ownership structure was tested. The significance of interaction between corporate control and ownership structure is an indicator of the presence of moderation. The Baron and Kenny (1986) approach in testing for moderation was employed for the purpose of this study guided by the equation:

$$
\mathrm{Y}=\beta_{0}+\beta_{1} \mathrm{X}+\beta_{3} \mathrm{XZ}
$$

Where

$\mathrm{X}=$ Independent variable (corporate control)

$\mathrm{Z}=$ Moderator (ownership structure)

$\mathrm{XZ}=$ Product of the standardized scores for the independent variable and the moderator.

\section{$\mathrm{Y}=\mathrm{ROA}$}

A $\mathrm{Z}$ score calculated as a product of the difference of data point and the mean divided by the standard deviation. It actually shows the number of standard deviation from the mean scores and helps locate values in the distribution being considered.

The $\mathrm{z}$-score derived as below:

$$
\mathrm{Z}=\frac{\mathrm{X}-\mu}{\sigma}
$$

$\mathrm{Z}=$ is the calculated score

$\mathrm{X}=$ is the data value

To create an interaction term, corporate control and the ownership structure was first centred and the two multiplied. A single item indicator representing the product of the two measures calculated and transformed into $\mathrm{Z}$ scores to eliminate possible multicollinearity. The resulting standardized variables (corporate control and the ownership structure) was then be multiplied to create the interaction variable. See table below:-

Table 4: The result of regression of the moderating effect of Ownership Structure on the relationship between CC and ROA

\begin{tabular}{|c|c|c|c|}
\hline & \multicolumn{3}{|c|}{ Coefficients } \\
\hline Variables & Model 1 & Model 2 & Model 3 \\
\hline Corporate control & $.824(.000)$ & $.523(.000)$ & $.596(.000)$ \\
\hline Ownership Structure & - & $.302(.018)$ & $.254(.027)$ \\
\hline CC ${ }^{*}$ OS & - & - & $.087(.006)$ \\
\hline R Square & .643 & .605 & .675 \\
\hline Adjusted R Square & .615 & .672 & .645 \\
\hline F Statistics & 502.453 & 246.098 & 198.564 \\
\hline Significance & .000 & .000 & .000 \\
\hline Df1 & 1 & 2 & 3 \\
\hline Df2 & 289 & 288 & 287 \\
\hline
\end{tabular}

The reading from the above table indicates that corporate control and ownership structure explains $67.5 \%\left(\mathrm{R}^{2}=.675\right)$ of the variation in corporate value. Statistics change upon combination also shows that $R^{2}$ change was 
$3.2 \%$ i.e. from .643 to $.675\left(\mathrm{R}^{2}\right.$ change $\left.=0.032\right)$ after the combination of the two interaction variables (Ownership structure and corporate control). There was a significant statistical change of $\alpha=0.05$ (p-value was 0.000). Based on this observation, there exists a statistically significant linkage between corporate control and ownership structure as confirmed by the $\mathrm{F}$ value of 198.564 and a p-value of 0.000 .

Further analysis shows statistically significant regression coefficients for corporate control with a $\beta$ of 0.824 and a $p$-value of 0.000 . This indicates a linear dependence of ROA on corporate control. Ownership structure and corporate value relations is also statistically significant when measured by ROA of $\beta=0.302$ with a p-value of 0.018 . Also, we observed that ROA on the combined terms of ownership structure and corporate control was also linear at $\beta=0.87$ with a $\mathrm{p}$ value $=0.006$. This indicates that changes in ownership structure may positively impact corporate control and corporate value given that the direction of the relationship is positive. We therefore failed to confirm the hypothesis that there is no significant moderating effect of ownership structure on the relationship between corporate control and corporate value.

The study indicates that there is a significant positive moderating effect of ownership structure on the relationship between corporate control and firm value as calculated by ROA. The result were supported by the finding of Bhabra (2007) who studied returns of companies listed at the New Zealand securities exchange and found that the relationship were significant and positive but not linear. The findings of Stulz (1990), studying management owners linkage with company results gave a concave relationship thereby partially supported this finding. However, results of Demsetz and Villalonga (2001) relating structure of ownership and corporate returns were not significant.

H2b: There is no significant effect of ownership structure on the relationship between corporate control and Tobin $Q$.

This sub hypothesis tests the impact of corporate control and ownership structure on Tobin Q. If the interaction between corporate control and ownership structure is significant, moderation is said to have taken place. The analysis of results were as represented in the table below. 
Table 5: Regression results of moderating effect of ownership structure on the relationship between corporate control and corporate value as measured by Tobin $Q$

\begin{tabular}{|c|c|c|c|}
\hline & \multicolumn{3}{|c|}{ Coefficients } \\
\hline Variables & Model 1 & Model 2 & Model 3 \\
\hline Corporate control & $.603(.000)$ & $.218(.068)$ & $.212(.092)$ \\
\hline Ownership Structure & - & $.354(.007)$ & $.305(.006)$ \\
\hline CC $*$ OS & - & - & $.192(.000)$ \\
\hline R Square & .264 & .273 & .345 \\
\hline Adjusted R Square & .283 & .294 & .336 \\
\hline F Statistics & 113.453 & 62.324 & 48.934 \\
\hline Significance & .000 & .000 & .000 \\
\hline Df1 & 1 & 2 & 3 \\
\hline Df2 & 289 & 288 & 287 \\
\hline
\end{tabular}

The reading of the table revealed that corporate control and ownership structure explains $34.5 \%\left(\mathrm{R}^{2}=.345\right)$ of the variation in corporate value. Observation of the change statistics from the table shows that $\mathrm{R}^{2}$ increased by $8.1 \%$ from .264 to $.354\left(\mathrm{R}^{2}\right.$ change $\left.=.081\right)$ when the combined effect of corporate control and ownership structure was considered. This statistical change is not significant at $\alpha=0.05$ ( $\mathrm{P}$-value $=.000$ ). There is therefore an insignificant association between ownership structure, company value and their interaction as the two models $2 \& 3$ shows p-value of .068 and .092 respectively.

The reading from the three models show statistically insignificant regression coefficients for corporate control of $\beta=.603$ with a $p$-value of .000 , showing that there is a straight line dependence of Tobin $\mathrm{Q}$ and corporate control. However, there is a significant association between structure of ownership and corporate value as calculated by Tobin's $Q$ of $\beta=0.354$ with a p-value of 0.007 .

The relationship between the structure of ownership and corporate value growth has been a topic of ongoing debate from the time of Berle and Means (1932). According to the duo, a company with a widely spread out owners generally underperform. A number of study findings are in support of the findings of this study. The study confirmed the findings of Shleifer and Vishny (1986) that thinly spread ownership tend to increases monitoring and supervisory expenses which results in reduced corporate value growth. The study was further supported by Fahlenbrach and Stulz (2009) finding that when owners hold substantial percentage of shares they tend to take keener interest in company management and put pressure on managers to realize faster value growth. The relationship between ownership concentration and corporate value have been confirmed by many other studies (Kang \& Shivadasani, 1995; Gedajlovic \& Shapiro, 1998; Short, 1994; Gorton \& Schmidt, 1996 and Thomsen \& Pederson, 2000). However, according to the 
argument of Demsetz and Lehn (1985) ownership concentration does not significantly affect value creation.

\section{Discussion and Research Findings}

One of our intention was to determine the impact of corporate control on the firm value of listed companies at the NSE. This was undertaken by analysing the financial statements and other relevant reports of the listed firms. The independent variable was examined under different sub constructs, namely, board structure and composition, corporate ethics, transparency, disclosures and auditing, board diversity and board remuneration. Correlation output indicated that linkage between corporate control and firm performance of quoted companies is statistically significant. Therefore Hypothesis H1 was not confirmed by the study results. Since the results confirmed that corporate control strongly influences the firm performance, good corporate controls principles and practices are likely to result in high growth in value.

Shleifer and Vishny (1997) found that the concentration ownership and corporate performance have a positive relationship. Gompers at al. (2003) later agreed with the findings that relationship between the two is of significant value. However, there were other findings which contradicted the study finding. A non-positive association between corporate control and company value growth was found by Ashbaugh et al. (2004) when they evaluated the effect of governance on company's operational effectiveness in value creation. No relationship was recorded by Hermalin and Weisbach (1996) when they measured the effect of board mix and corporate growth. Further, Daily and Dalton (1992) findings did not show any relationship between corporate control and corporate performance even after applying accounts and market indicative workings.

The second objective of the study was to establish the moderating effect of ownership structure on the linkage between company control and corporate value. The hypothesis that there is no significant moderating effect on the linkage between corporate control and corporate value was testing by applying Baron and Kenny (1986) approach. The study output showed a significant interaction between corporate control, ownership structure and corporate value determined by ROA and Tobin $\mathrm{Q}$. The hypothesis that that there are no significant influence of corporate control and corporate performance as moderated by ownership structure was therefore not confirmed. A few of studies have been done linking corporate control or governance to firm performance with ownership structure as a moderating variables.

Mediation was further tested by exploring the possibility of a mediating effect of ownership structure in the influence of corporate control on firm value growth. The output provided sufficient statistical evidence to 
signify a mediation relationship. The implication of this is that the ownership structure, corporate control and corporate value do have a direct relationship, and that the interaction of ownership structure and corporate control increases the influence on firm returns.

Oxelheim and Randoy (2003) found foreign board membership had a positive influence on corporate value growth. The same was supported by others studies (Baek et al., 2004 \& Park, 2004) findings of significant linkage between foreign ownership and company value improvement. Although a number of studies are in support of the finding of this study and have found a significant and positive relationship of concentrated ownership on corporate performance (Mitton, 2002 \& Joh, 2003. Sanchez and Garcia, (2009) found a non-linear relationship between ownership concentration and firm performance. Dalton et al., (2003) and Sanchez and Garcia, (2009) findings indicated a concave association concerning ownership structure and corporate value. A number of papers have provided comprehensive survey and found that on impact of concentration factor in ownership are mixed (Gugler, 2001; Shleifer \& Vishny, 1997 and Short, 1994).

\section{Conclusion}

In conclusion, the study test results has underscored the weight given to corporate control in enabling firms to achieve consistent high value. The ownership structure plays a key part in influencing the linkage concerning corporate control and corporate value growth and should play a key role in adopting good governance principle to achieve enhanced performance. The study has shown that agency problems can be aggravated by high voting rights which may result in pyramid ownership structures and crossholding. The resulting situation results in over-reliance on debt resulting from main shareholders desire to preserve their shareholding from dilution. This is the phenomenon which Claessens et al. (2002) referred to as non-dilution entrenchment. The study findings were in line with the observation that proprietorship centeredness improves company control and hence value creation as it reduces agency cost. A positive association concerning ownership concentration and company growth were also found by other studies (Margaritis \& Psilaki, 2010 and Himmelberg et al., 1999). Other than high proportion of shares per owner, identity or mix of ownership is important in understanding variation in company's effectiveness in value creation. Here foreign and State shareholdings were examined. The findings indicates that depending on the appropriateness of board structure, ownership structure and corporate financial policies have potential mechanisms to control for agency problem arising from dispersed ownership. Similar findings were noted by Jensen, 1986. 
The results show the importance of corporate control for growth of company value and shareholders' equity. It was found that large board size increases corporate value as they have a large number of expertise for better decision making, making it more difficult for CEO to manipulate. In addition to satisfying the regulatory requirement, the board also plays a crucial role in addressing company problems. Our findings indicated that smaller size of board helps improve corporate performance and value through efficient use of resources. It was noted that when payment is linked to performance, it act as an incentive for improve performance and greater effort and also to reduce the effect of agency problem thereby positively affecting firm value. It was also evident that corporate control can be enhanced by increasing accountability and promoting sustainable wealth creation.

The study therefore concludes that the central appreciative in the arena of corporate control has its basis on the fact that there is a potential problem originating from the parting of ownership and control which has been necessitated by the growth in size and complexities of corporation. The results were in line with this understanding and showed existence of significant and positive link concerning corporate control and firm value. The conclusion is supported by previous research findings (Shleifer \& Vishny, 1986). The results show the importance of corporate control for growth of firm performance and shareholders' equity. We have also seen that ownership structure moderation in the relationship of corporate control and firm value is valuable to the company performance. Each of the two variables (corporate control and capital structure) had significant joint contribution to the corporate value as determined by Return on company resources and Tobin Q.

\section{Contribution to Knowledge}

The study has contributed to the existing knowledge by providing empirical evidence that the structure of ownership has a moderating effect on corporate control and corporate value growth. The study has also combined important mechanism in CCI and OSI to establish the effect of corporate control and ownership structure on corporate value growth which has provided new insight and increase the number of variables and sub variables thereby enriching the result. The study will be invaluable to future researcher as it provide a rich base on knowledge on which to build future research. The study therefore contributes to theory, methodology as well as practice.

\section{Limitation of the Study}

Under ownership, we considered only ownership concentration, foreign ownership and state ownership while others like domestic ownership, institutional ownership, and corporate ownership among others could also have some effect. The secondly the scope of the study was only limited to 
those companies listed in Nairobi stock exchange within the last five years which may make the study not be generally applicable to other developing countries in Africa and beyond as well as developed countries.

The above limitations do not dilute the value of the findings. Its findings has a far reaching input to corporate world, researchers and general understanding touching on areas of corporate control and governance which still has a lot of room for future studies.

\section{Recommendation and Policy Implication}

The study reveals the importance played by the government and other regulatory authorities in issuing a number of regulations and policies to continually strengthen corporate control and ensure stable and increasing corporate performance. Since individual firm's performance is intrinsically linked to the entire country's economic well-being, the authorities are able to guide, improve and increase economic growth through these regulations and policies. This also help in ensuring that board members and company leaders has required qualification and experience as well as the necessary competency to drive growth and reduce conflict of interest.

\section{Suggestion for Future Research}

Future researchers need to incorporate other performance measures, both financial and non-financial other than just ROA and Tobin Q considered above for measuring firm value. For measurement of ownership structure, they may consider also block investors, directors' ownership, and government ownership among others. Corporate control can also include such variables as corporate social responsibility, family board members among others.

\section{References:}

1 Ashbaugh, H., Collins, D. S., \& LaFond, R. (2004). Corporate governance and cost of equity capital. Journal of Accounting and Economics 42(3), 203-243.

2 Baek, J. S., Kang, J. K., \& Park, K. S. (2004). Corporate Governance and Firm Value: Evidence from the Korean Financial Crisis. Journal of Financial Economics, 71 (2), 265-313.

3 Barclay, M. J., \& Holderness, C. G. (1991). Negotiated Block Trades and Corporate Control. Journal of Finance, 46 (3), 861-878.

4 Berle, A. A. \& Means, G. C. (1932). The Modern Corporation and Private Property. The Macmillan Company, New York, NY.

5 Bhabra, G. S. (2007). Managerial ownership and firm-value in New Zealand. Journal of Multinational Financial Management, 17(5), 142-154. 
6 Black, B. S., Jang, H., \& Kim, W. (2006). Does corporate governance predict firms' market values? Journal of Law, Economics, and Organization, 22 (2), $366-413$.

7 Brown, L., \& Caylor, M. (2006). Corporate governance and firm Valuation, Journal of Accounting and Public Policy, 25(4), 409-434.

8 Chagbadari M. F. (2011). Corporate governance and firm performance, International Conference on Sociality and Economic Development, 10 (1), 484-489.

9 Claessens, S, S. Djankov, J. P., Fan, H., Larry H. P., \& Lang, (2002). Disentangling the Incentive and Entrenchment Effects of Large Shareholdings, Journal of Finance, 57(1), 41-71.

10 Dalton, D. R., \& Daily, C. M. (1992). The relationship between governance structure and corporate performance. Journal of Business Venturing, 32, 375-386.

11 Dalton, D. R., Daily, C. M., Certo, S. T., \& Roengpitya, R. (2003). Meta-Analyses of Financial Performance and Equity: Fusion or Confusion? Academy of Management Journal, 46 (5), 13-26.

12 Demsetz, H., \& Lehn, K. (1985). The structure of corporate ownership: Causes and consequences, Journal of Political Economy, 93(9), 55-77.

13 Demsetz, H., \& Villalonga, B. (2001). Ownership structure and corporate performance. Journal of Corporate Finance, 7(3), 209233.

14 Denis K. (2001). Twenty-five years of corporate governance research and counting. Journal of Review of Financial Economics, 10, 191212.

15 Dominic, O. O., \& Memba, F. (2015). Effect of corporate governance practices on financial performance of public limited companies in Kenya. International Journal of Management and Commerce Innovations (3)1, 122-132.

16 Donaldson, L. (1990). The Ethereal Hand: Organizational Economics and Management Theory, Journal of Management Review, 15(4), 369-81.

17 Eyenubo A. S. (2013). The impact of bigger board size on financial performance for firms: the Nigerian experience. Journal of Research in International Business and Management, 3(3), 85-90.

18 Fahlenbrach, R., \& Stulz, R. M. (2009). Managerial ownership dynamics and firm value, Journal of Financial Economics, 92 (3), 342-361.

19 Fauzi, F., \& Locke, S. (2012). Board Structure, ownership structure and firm performance: A study of New Zealand Listed-firms. Asia 
Academy of management journal of accounting and finance, 8(2), 4367

20 Gedajlovic, E., \& Shapiro, D. 1998. Management and Ownership Effects: Evidence from Five Countries. Strategic Management Journal, 19(12), 533-553.

21 Gompers, P., Ishii, J., \& Metrick, A. (2003). Corporate Governance and Equity Prices, Quarterly Journal of Economics, 118(1), 107-155.

22 Gorton, G., \& Schmidt, F. (1996). Universal Banking and the Performance of German Firms. National Bureau of Economic Research. Working Paper no. 5453, Cambridge: MA.

23 Gugler, K. (2001). Corporate Governance and Economic Performance. New York: Oxford University Press.

24 Gursoy, G., \& Aydogan, K. (2002). Equity ownership structure, risk taking, and Performance. Emerging Markets, Finance \& Trade. 38(6), 6-25.

25 Hansmann H. (2000). The Ownership of Enterprise. The belknap press of Harvard University press. England. 11-12.

26 Hermalin, B. E., \& Weisbach, M. S. (2003). Boards of directors as an endogenously determined institution: A survey of the economic literature. Economic Policy Review, 9(1), 7-26.

27 Hermalin, B. E. \& Weisbach, M. S. (1996). The effects of board composition and direct incentives on firm performance, financial management, 20(4), 101- 123.

28 Himmelberg, C. P., Hubbard, R. G. \& Palia, D. (1999). Understanding the determinants of managerial ownership and the link between ownership and performance. Journal of Financial Economics 53, 353-384.

29 Jensen, M. C. (1986). Agency costs of free cash flow, corporate finance, and takeovers. American Economic Review 76, 323-329.

30 Jensen, M., \& Meckling, W. (1976). Managerial behavior, agency costs and ownership structure. Journal of financial economics, 3, 305 -360 .

31 Joh, S. W. (2003) Corporate Governance and Firm Profitability: Evidence from Korea before the Economic Crisis. Journal of Financial Economics, 68 (7), 287-322.

32 Kang, J, \& Shivdasni. A. (1995). Firm Performance, Corporate Governance, and Top Executive Turnover in Japan. Journal of Financial Economics, 38(3), 29-58.

33 Kiruri, R. M. (2013). The effects of ownership structure on bank profitability in Kenya. European Journal of Management Sciences and Economics, 1(2), 116-127. 
34 Lauterbach, B. \& Vaninsky, A., (1999). Ownership Structure and Firm Performance: Evidence from Israel. Journal of Management and Governance 3(2), 189 - 201.

35 Lee, S. (2008). Ownership structure and financial performance: Evidence from Panel data of South Korea. University of Utah. Department of economics working paper series, working paper no. 2208-17.

36 Margaritis, D., \& Psilaki, M. (2010). Capital structure, equity ownership and firm performance. Journal of Banking and Finance, 34(3), $621-632$.

37 Mitton, T. (2002). A Cross-Firm Analysis of the Impact of Corporate Governance on the East Asian Financial Crisis. Journal of Financial Economics, 64(3), 215-241.

38 M'Ithiria, E. N., \& Musyoki, D. (2014). Corporate governance, ownership structure perspective and firm value: theory, and survey of evidence, International Journal of Research in Management \& Business Studies, 27, 1-3.

39 Mwangi, L.M, Makau, M.S \& Kosimbei, G (2014). The relationship between Capital Structure and Performance of Non-Financial Companies Listed in the Nairobi Securities Exchange, Kenya". Global Journal of Contemporary Research in Accounting, Auditing and Business Ethics, 1 (2), 32-55.

40 OECD (2004). OECD Principles of Corporate Governance, Revised version, Organization for economic co-operation and development (OECD), Paris.

41 Olson, K. (2008). The relationship between stewardship theory of management and employee engagement: A case study exploration of the leadership philosophy of a professional services firm. Retrieved from A Midwest Academy of Management Web site: www.midwestacademy.org/Proceedings/2008/papers.

42 Okiro, K., Aduda, J., Omoro, N. (2015). Effect of corporate governance and capital structure of performance of firms listed at the East African community securities exchange. European Scientific Journal, 11(7), 504-533.

43 Omondi, M. M. \& Muturi, W. (2013). Variables affecting the financial performance of listed companies at the Nairobi Securities exchange in Kenya. Research Journal of Finance and Accounting, 4 (15), $100-115$.

44 Oxelheim, L. \& Randøy, T. (2003). The Impact of Foreign Board Membership on Firm Value. Journal of Banking and Finance. 27 (6), 69-92. 
45 Park, Y. S. (2004). Assessing The Impact Of Corporate Governance On Productivity And Growth In Korea. In E. T. Gonzalez (ed.) Impact of Corporate Governance on Productivity: Asian Experience. Asian Productivity Organization.

46 Sanchez-Ballesta, J. P. \& Garcia-Meca, E. (2007). A Meta-Analytic Vision of the Effect of Ownership Structure on Firm Performance. Corporate Governance, 15(11), 879-893.

47 Shleifer, A., \& Vishny, R. W. (1997). A Survey of corporate governance. Journal of Finance, 52(2), 737-783.

48 Thomsen, S., \& Pedersen, T. (2000). Ownership structure and economic performance in the largest European companies. Strategic Management Journal, 21, 689-705.

49 Short, H. 1994. Ownership, Control, Financial Structure and Performance of Firms. Journal of Economic Surveys, 8(7), 209-249.

50 Solomon, M. C., Gerald, M. M., Alala, O.B., Douglass, M. \& Maokomba, O. C. (2013). Capital structure and corporate governance practices. Evidence from listed non-financial firms on Nairobi security exchange. Journal of Business Management, 10(2), 8-16.

51 Sternberg, E. (1997). The defects of stakeholder theory. Corporate Governance: An International Review, 3-10.

52 Stulz, R. (1990). Managerial discretion and optimal financing policies. Journal of Financial Economics, 26, 3-27.

53 Thomsen, S., \& Pedersen, T. (2000). Ownership structure and economic performance in the largest European companies. Strategic Management Journal, 21, 689-705.

54 Waweru, N. M., \& Riro, G.K. (2013). Corporate Governance, Firm Characteristics and Earnings Management in an Emerging Economy, Jamar, 11 (1), 27-52.

55 Wanjugu, G. E, Kibet, K. S., \& Kisaka, S. E. (2015). The influence of ownership structure and corporate governance reforms on profitability and market value of privatized companies in Kenya, International Journal of Economics, Commerce and Management, 3(12), 314-330. 